\title{
The Harmony of Instructional Communication in the Classroom
}

\author{
I Wayan Rasna* \\ Prodi Pendidikan Bahasa \\ Universitas Pendidikan Ganesha Singaraja \\ Singaraja, Indonesia \\ *wayanrasna@ymail.com \\ Ni Wayan Sariani Binawati \\ Prodi Dharma Acarya \\ Institut Hindu Dharma Negeri Denpasar \\ Denpasar, Indonesia \\ wsbinawati@yahoo.com
}

\author{
Dewa Komang Tantra \\ Prodi Pendidikan Bahasa Inggris \\ Universitas Pendidikan Ganesha Singaraja \\ Singaraja, Indonesia \\ dewatantra@yahoo.com \\ I Nyoman Tri Anindia Putra \\ Prodi Teknik Informatika \\ Sekolah Tinggi Ilmu Komputer Indonesia \\ Denpasar, Indonesia \\ trianindiaputra@gmail.com
}

\begin{abstract}
This study aimed to analyze 1) the forms of politeness-based instructional communication in building social harmony in the classroom. This study was done to senior high school and vocational school students in Singaraja town through several techniques, recording, observation, interview, and documentation (photos). The results showed that the forms of instructional communication that can build social harmony in the classroom were: 1) verbal appreciation, 2) verbal reminder, 3) motivation in the form of an invitation, 4) giving examples, 5) persuasive metaphor, and 6 ) ability to cooperate.
\end{abstract}

Keywords—communication, instruction, social harmony

\section{INTRODUCTION}

The deviation from the principle of politeness in language causes disturbance in instructional communication [1]. Related to this, language politeness is necessary when there is an interaction between the speaker and listener [2]. In an interaction, there is a probability for the potentiality of cooperation or conflict [3]. Conflict can become the source of violence that starts from the hurt of feeling [2], especially if it involves impolite young people who do not have good manners [4]. This will make it easy for provoking emotion that has a harmful effect, for example, using the sentence: You are stupid, lazy, and naughty. This will have a psychological impact on students, such as they will feel inferior and do not dare. Many people cannot use polite words well and appropriately to avoid a rude impression [5]. Avoidance of harsh impressions is crucial since communications have complex dimensional effects, including educational communication [6]. This complex dimension occurs since in communicating a message, a person pays attention to the content or the core of the information, and norms, rules, and speakers have to pay attention to them [7]. This is because speakers need to keep harmony with the interlocutors [8]. In this context, the maintenance of the balance of relations is done by maintaining the harmony of word functions and cultural functions [9], starting from the prenatal period when parents have to think, speak and behave politely [10-12]. Thus, the study's objectives were to identify: (1) the forms of language politeness-based instructional communication for building social harmony in the classroom? And (2) how teachers manage language politenessbased instructional communication for creating social balance in the classroom.

\section{METHODS}

This study used a qualitative design [13] since it focused on the etic and emic holistic description of the superstructure speech forms used as the guidance to act in the community in its sociocultural environment [14]. The subjects were the senior high schools and vocational schools teachers in Singaraja. The data were the forms of speech and the data on the management of instructional communication based on language politeness in building social harmony in the classroom were collected using the technique of a) recording, b) observation, c) interview, and d) documentation (photos). The researchers used recording techniques to obtain data in the form of the teachers' speeches and students at the time of teaching in verbal communication. At the same time, the researchers received nonverbal communication by taking pictures or documentation. The unreachable data through recording and photos were collected through interviews, especially on social harmony from the students. The data collected were analyzed using the following stages. 
- Arrangement of the collected data

- Categorization of data in concepts, propositions, and patterns based on the similarities or those that can be assumed to be similar.

- Interpretation of data

- Formulation of temporary conclusions based on data similarities

- Matching the temporary conclusions based on data validity before being formulated as general conclusions.

- Revision of conclusions by finding the relatedness between the ideological things and the study's problems [15].

\section{FINDING AND DISCUSSION}

\section{A. The forms of Instructional Communication}

1) Verbal appreciation as motivator: The teaching in the classroom does not only require the presence of an increase in the students' intellectual quality, but it also involves the sensitiveness of feelings on the part of the teachers/ lecturers to understand the students' psychological condition in the effort to build social harmony in the classroom. Thus, teaching cannot be reduced into the effort to equalization of cognitive, affective, and psychomotor aspects [16]. But it is crucial to understand the students' psychological condition since this can be very helpful for creating harmony in the classroom, as shown by the following data.

(1) Teacher: The answer is very accurate. In addition to his use of sentences that use the standard language, he uses complete structures that are easy to understand, and he also has a good spirit of learning (the teacher erases the whiteboard). I want other students to do the same. Please, who can?

(2) Student: Let me try, Madam. Folklore has didactic values and entertaining values, especially if presented in the video format.

(3) Teacher: Well done!

The verbal appreciation given by the teacher to the student in the form of " the answer is very accurate" and " Well done, " of course, are the statements that have motivational values not only for the students who are successful in answering the question but also for the other students to be enthusiastic about achieving. The students' self-confidence will develop in those who have not had it, and for those who have already had selfconfidence, the self-confidence will become stronger.

The students' satisfaction will be met when the teacher gives a statement or an utterance in the form of praise or flatter for their achievements. Praise or flatter can be given not only in a verbal statement like good, very accurate, well done, excellent, etc. It can also be given nonverbally in hands clapping and thumb up. Both verbal and nonverbal statements show a solidarity attitude that makes symmetrical relation between the teacher and the students. This symmetrical relation will encourage the development of social harmony in instruction, without the necessity of showing the teacher's hegemony that has an impact on the reduction of the quality of interactions in learning.

Now the positioning of a teacher-student hegemony has no place in the students' hearts. Since the teacher-student hegemony paradigm that is asymmetrical is not suitable for the millennial generation since they prefer symmetrical relation to an asymmetrical relation.

2) Verbal reminder: Before the lesson, the media such as whiteboard markers were not prepared by the student assigned. The effect is that the teacher cannot write on the whiteboard, and the teacher would say something like in sentences (4).

(4) Teacher: Remember your responsibility. If it is like this, will the learning process be postponed or not? In the future, please have good cooperation, will you?. The teacher's sentence says," In the future, please have good cooperation, will you? It is a soft verbal reminder from a teacher.

3) Motivation in the form of an invitation: Motivation in the form of an invitation is the realization of the humanistic teaching ideology that prioritizes symmetrical relations between the teacher and the students in instruction, such as in example (5) below.

(5) Let us learn how to speak politely together, to make our interlocutors comfortable. This sentence shows that the teacher positions himself or herself equally with the students by learning together. This, of course, can strengthen the students' motivation since the teacher has to learn.

4) Giving examples. An example that can clarify the material presented is not only essential to help the students understand the lesson, but it is also important to motivate them to learn, as in example (6).

(6) When Covid 19 is devastating all the world, without anyone knowing where it is hiding, then all of a sudden human beings are tested positive based on a swap. In this situation, I am aware of God's great power.

This example is expected to open an experience and describe the students' imagination in a paragraph that will gradually be developed into a larger series. These two examples are expected to open the students' minds to the greatness of God so that they will become strong not only cognitively but also spiritually.

5) Persuasive metaphor. A persuasive metaphor is a form of polite expressions that the speaker intends to convince and 
influence his or her interlocutor, especially to do an action expected by the speaker, like in example (7) below.

(7) Student: Sir, please give us 15 more minutes.

Teacher: All right. Fifteen minutes is enough for you to go home, for those who live far from the school.

The teacher's sentence in (7) is the teacher's persuasive metaphor of refusal to avoid a direct refusal. Persuasive metaphors can also be found in example (8).

(8) Teacher: Yes. The answer is almost perfect. It will become perfect when the sentence is changed into a polite one.

6) Ability to cooperate. Working together in learning is vital to reach the learning group's objective. To achieve this it one needs to try 1) to understand each other and trust each other; 2) to be able to communicate clearly and understandably; 3) to support each other; 4) to try to maximize the effort to solve differences of opinions that are oriented toward conflict. This is necessary by 102 respondents $(85 \%)$ of 120 respondents. Based on this, if it is illustrated will look like Figure 1.

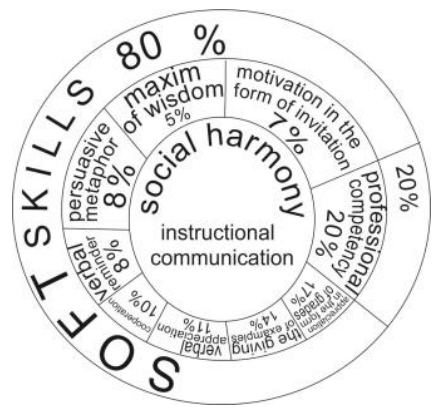

Fig. 1. Forms of instructional communication.

Based on the figure 1 of forms of instructional communication, we know that the harmony of instructional communication in the classroom is $80 \%$ determined by soft skills, like appreciation, both verbal and values, the giving of actual examples, verbal reminder, persuasive metaphor, the maxim of wisdom and motivation. All of these are closely related to an increasingly stronger social relation. These are the strong factors of instructional communication harmony.

\section{CONCLUSION}

Based on the results of the analysis, this study concluded that the forms of language politeness-based communication in building social harmony are: 1) verbal appreciation as a motivator $(11 \%) ; 2$ ) verbal reminder $(8 \%) ; 3)$ motivation in the form of an invitation (7\%); 4) giving simple and actual examples $(14 \%) ; 5)$ persuasive metaphor (8\%); and 6) ability to cooperate/ associate (10\%). Considering the results of the study, the researchers suggest that it is the time for the teachers to change the asymmetrical paradigm that considers that teachers are the authorities in teaching into the symmetrical paradigm that considers that the teacher and the students are friends in learning.

\section{ACKNOWLEDGMENT}

The authors would like to express their gratitude to 1) The Rector of Ganesha University of Education with all of his staffs, 2) Director of Postgraduate Studies of Ganesha University of Education, and 3) Head of Institute of Research and Community Service of Ganesha University of Education for the fund for the research and the administrative service given in accomplishing this study.

\section{REFERENCES}

[1] R. Wulandari, E. Martha, E. Guspaneza, A. Cendanasari, L. Agustiyah N. Nurhotimah and S. Mahrudin, "Exclusive Breastfeeding among Working Mothers in Jabodetabek, Indonesia," in The 6th International Conference on Public Health 2019, 2019, no. June, pp. 183-195, doi: 10.26911/the6thicph-fp.03.02

[2] I.W. Rasna, "Workshop Implementasi Pendidikan Karakter yang Terintegrasi dalam Rangka Penyiapan SDM di Era Revolusi Industri 4.0 pada Guru SMP dan SMK di Kabupaten Badung dan Kodya.” pp. 1-7, 2019

[3] D. Kartika, "Budaya Malu dan Tindak Bertanya pada Pemelajar Program BIPA di Fakultas Ilmu Pengetahuan Budaya Universitas Indonesia," in Proseding Konferensi Internasional Linguistik Atmajaya, 2004, pp. 67-70.

[4] E.B. Surbakti, Kenalilah Anak Remaja Anda. Jakarta: PT Elex Media Komputindo, 2009.

[5] D.W. Rohaedi, "Kesantunan Berbahasa di Ruang Kelas dalam Wacana Bahasa Mengukuhkan Identitas Bangsa," Bandung, 2009.

[6] N.A. Setyanto, Interaksi dan Komunikasi Efektif Belajar-Mengajar. Yogyakarta: Diva Press, 2017.

[7] Z.S. Nakrowi and A. Fujiyanti, "Strategi Kesantunan Berbahasa Suku dalam Interaksi Antarsuku Jawa di Halmahera Utara dalam," RETORIKA J. Bahasa,Sastra,dan Pengajarannya, vol. 12, no. 1, pp. $105-116,2019$

[8] S. Rustono, "Kesantunan Tuturan Penyiar Televisi pada Wacana Siaran Prgram Hiburan Televisi Swasta Indonesia,” J. Seloka Pendidik. Bhs. danSastra Indones., vol. 6, no. 3, pp. 297-306, 2017.

[9] E. Kuntarto, "Studi Semantik-Komparatif Kesantunan dalam Bahasa Inggris Melayu, Indonesia, dan Jawa,” J. Belajar Bhs., vol. 3, no. 2, pp. 150-166, 2018.

[10] M. Awanita, Membentuk Kepribadian Anak dalam Kandungan Suranaya: Paramita, 2008.

[11] A. Wahyono, "Psikologi Kognitif Cakupannya, Sejarah Perkembangan," J. Psikol., vol. 36, no. 2, 2012

[12] M.E. Purnomo, "Kecenderungan Linguistik Dewasa ini dan Perkembangan Metode Pembelajaran Bahasa," J. Forum Pendidik., vol. 29 , no. 1 , p. 57,2009 ,

[13] M.B. Miles, A.M. Huberman, and J. Salda, Qualitative Data Analysis, 3rd Editio. London: SAGE Publication, 2014.

[14] C. Geertz, Kebudayaan dan Agama Budisantoso. Yogyakarta: Kanisius, 1999.

[15] P.F. Carspecken, Critical Ethnography in Educational Research: A Theoretical and Practical Guide. New York: Routledge, 1998.

[16] R. Puspitorini, A. K. Prodjosantoso, B. Subali, and J. Jumadi, "Penggunaan Media Komik dalam Pembelajaran IPA untuk Meningkatkan Motivasi dan Hasil Belajar Kognitif dan Afektif," Cakrawala Pendidik., vol. 33, no. 3, pp. 413-420, 2014. 